\title{
Effect of Application of Ammonium Chloride and Calcium Chloride on Alfalfa Cation-Anion Content and Yield ${ }^{1}$
}

\author{
J. P. Goff, ${ }^{\star 2}$ E. C. Brummer, $†$ S. J. Henning, $†$ R. K. Doorenbos, $\nmid$ and R. L. Horst ${ }^{\star}$ \\ ${ }^{*}$ Periparturient Diseases of Cattle Research Unit, National Animal Disease Center, USDA-Agricultural Research Service, Ames, IA 50010-0070 \\ †Agronomy Department, lowa State University, Ames 50011
}

\begin{abstract}
A major factor predisposing the cow to periparturient hypocalcemia, or milk fever, is being fed a prepartum ration with a high dietary cation-anion difference (DCAD). The DCAD can be favorably altered to prevent milk fever by decreasing $\mathrm{K}$ and $\mathrm{Na}$ or increasing $\mathrm{Cl}$ and $\mathrm{S}$ in forages for cows in late gestation. The objective of this study was to test the hypothesis that application of $\mathrm{Cl}$ to alfalfa could increase $\mathrm{Cl}$ in forage, thereby lowering DCAD. We conducted a field experiment at 2 Iowa locations in which established plots of alfalfa were treated in April 2001 with 0, 56, 112, or $168 \mathrm{~kg}$ of $\mathrm{Cl} /$ ha using ammonium chloride, calcium chloride, or a mix of the 2 sources with equal amounts of chloride coming from each source. Plots were harvested 4 times in 2001 and once in 2002 and plant tissue analyzed for mineral composition. Applying chloride from either source once in the spring resulted in increased plant chloride content over all 4 cuttings for that year. Averaged across both locations, chloride levels were elevated from $0.52 \%$ in control plots to $0.77,0.87$, and $0.89 \%$ $\mathrm{Cl}$ in plots treated with 56, 112, and $168 \mathrm{~kg}$ of $\mathrm{Cl} / \mathrm{ha}$, respectively. Chloride application had no effect on plant potassium, sodium, calcium, magnesium, or phosphorus. These results suggest chloride application can elevate chloride content and lower DCAD values of alfalfa, and also maintain crop yield.
\end{abstract}

Key words: dietary cation-anion difference, chloride, alfalfa, milk fever

\section{INTRODUCTION}

At the onset of lactation, the demands for milk production can induce a condition of low blood $\mathrm{Ca}$ in the

Received January 31, 2007.

Accepted July 16, 2007.

${ }^{1}$ Names are necessary to report factually on available data; however, the USDA neither guarantees nor warrants the standard of the project, and the use of the name by the USDA implies no approval of the project to the exclusion of others that may also be suitable.

${ }^{2}$ Corresponding author: jesseg@westcentral.net dairy cow. In some cases, the blood Ca concentration falls below the level necessary to support nerve and muscle function and the cow becomes recumbent, resulting in a condition known as hypocalcemia or milk fever. Dietary cations, in particular K, inhibit the homeostatic mechanisms that ordinarily maintain blood Ca concentration within normal limits by inducing a metabolic alkalosis in the cow. This interferes with the function of parathyroid hormone, the primary Ca-regulating hormone (Goff et al., 1991). Increasing dietary anions (particularly $\mathrm{Cl}^{-}$) can help overcome the effects of dietary cations because anions acidify the blood of the cow, enhancing target tissue sensitivity to parathyroid hormone and permitting Ca homeostasis (Dishington, 1975; Block, 1984; Goff and Horst, 1998).

Ration formulation for dairy cows just prior to parturition must control the DCAD if hypocalcemia and milk fever are to be avoided. One key to reducing hypocalcemia is to avoid incorporation of high $\mathrm{K}$ forages into the ration. Dairy rations must incorporate some proportion of forage (usually at least 40\%) to provide the effective fiber vital to the function of the cow's rumen (Mertens, 1997). Alfalfa and cool season grasses utilizing the $\mathrm{C}_{3}$ photosynthetic system, such as orchardgrass and brome, are often used in dairy rations. Because these plants will accumulate $\mathrm{K}$ well beyond their needs if $\mathrm{K}$ is present at high concentrations in the soil, plant tissue K levels can reach 4\% DM (Lanyon and Smith, 1985). The excessive $\mathrm{K}$ content of these forages can cause metabolic alkalosis in the cow and subsequently increases the risk of hypocalcemia and milk fever. Reducing $\mathrm{K}$ content of forages can be achieved by restricting $\mathrm{K}$ application so that soils do not support excessive accumulation of $\mathrm{K}$ by the plants (Lanyon and Smith, 1985; Kelling and Matocha, 1990). More than half of the dairy cows in the United States are now fed late gestation rations that utilize low $\mathrm{K}$ forages to limit $\mathrm{K}$ intake (NAHMS, 2002). If, in addition to decreasing forage $\mathrm{K}$, the producer can also increase the $\mathrm{Cl}$ content of the forages, the resulting DCAD will be more favorable for the late gestation cow. Thomas et al. (1998) and Pehrson et al. (1999) demonstrated the chloride content of grasses can be increased markedly by addition of chlo- 
ride to the soil. These findings may also be applicable to legumes such as alfalfa.

This study tests the hypothesis that application of chloride to alfalfa will increase plant tissue chloride levels and reduce DCAD of the forage. The objective of the experiment was to fertilize alfalfa with $\mathrm{CaCl}_{2}$ or $\mathrm{NH}_{4} \mathrm{Cl}$ or a combination of both and to measure the concentrations of the major cations and anions in the alfalfa tissue and to monitor forage yield.

\section{MATERIALS AND METHODS}

Field experimental plots were planted at the Agronomy and Agricultural Engineering Research Farm west of Ames, IA, in a Nicollet loam soil (fine-loamy, mixed, superactive, mesic Aquic Hapludolls) in April 2000 and at the Northeast Research Farm south of Nashua, IA, in a Readlyn loam soil (fine-loamy, mixed, mesic Aquic Hapludolls) in April 2000. The experiment at each location consisted of $0.9 \times 3.7 \mathrm{~m}$ plots, with fertility treatments arranged in a randomized complete block design with 4 replications. Alfalfa (Medicago sativa) seed (Pioneer 5454 alfalfa cultivar, Pioneer Hi-Bred International Inc., Johnston, IA) was drilled at $17 \mathrm{~kg} / \mathrm{ha}$ in plots consisting of 5 rows spaced $15 \mathrm{~cm}$ apart at each location. All seed was treated with Sinorhizobium meliloti prior to planting. The entire plot area was bordered by alfalfa. The selective herbicide EPTC (s-ethyl dipropylthiocarbamate) was applied at $4.67 \mathrm{~L} / \mathrm{ha}$ for preemergent weed control. Potato leafhoppers (Empoasca fabae [Harris]) were controlled by spraying permethrin (Pounce) [3-(phenoxyphenyl) methyl (+,-)-cis, trans-3(2,2-dichloroethenyl)-2,2-dimethyl cyclopropanecarboxylate (approximately 60\% trans, $40 \%$ cis isomers)] twice in 2000 and 2001.

Chloride treatments were applied once at the beginning of the 2001 growing season. Chloride fertilizer was applied as $\mathrm{NH}_{4} \mathrm{Cl}, \mathrm{CaCl}_{2}$, or an equal mixture of $\mathrm{NH}_{4} \mathrm{Cl} /$ $\mathrm{CaCl}_{2}$ (based on $\mathrm{Cl}$ concentration) at $0,56,112$, or 168 $\mathrm{kg}$ of $\mathrm{Cl} / \mathrm{ha}$. Chloride treatments were applied as $20 \%$ (wt/vol) salt solutions, and the volume of each applied to the plots was adjusted to achieve the desired chloride application rate. The alfalfa was harvested 4 times during 2001, and a fifth cutting was made in May 2002. At each harvest, plots were harvested with a sickle bar-type harvester equipped with an electronic weigh system. Prior to harvest, subsamples were taken to adjust plot yields for moisture content and to analyze mineral content. Subsamples were dried at $60^{\circ} \mathrm{C}$ for 4 $\mathrm{d}$, after which they were ground to pass through a 1mm screen.

Mineral content of the soil in each plot was determined in April, prior to application of the treatments, and again in July of 2001, after the second cutting was harvested. Exchangeable cation concentrations were determined following ammonium acetate extraction (Warncke and Brown, 1998). Soil chloride and sulfur concentrations were determined on deionized water extracts of the soil, which were then analyzed by the same methods used on plant tissues. Mineral concentrations in plant tissues were determined by Dairyland Labs (Arcadia, WI). The $\mathrm{Na}, \mathrm{K}, \mathrm{Ca}, \mathrm{Mg}$, and $\mathrm{P}$ determinations were made by inductively coupled plasma-mass spectrometry on samples that had been dry-ashed and redissolved in $1 \mathrm{~N} \mathrm{HCl}$. Sulfur determinations were done by inductively coupled plasma-mass spectrometry on samples that had undergone microwave digestion in nitric acid. Chloride was determined using a Corning Chloride Analyzer (Corning Medical and Scientific, Medford, MA), which is based on precipitation of $\mathrm{Cl}$ as silver chloride in samples blended with water. The DCAD of each forage sample was calculated as $\mathrm{mEq}$ of $\left(\mathrm{Na}^{+1}+\mathrm{K}^{+1}\right)-\left(\mathrm{Cl}^{-1}+\mathrm{SO}_{4}^{-2}\right) / \mathrm{kg}$ of DM.

\section{Statistical Analysis}

Mineral content of the plant tissues is expressed as a \% (wt/wt) of DM. Data from both Ames and Nashua plots were combined in an initial factorial ANOVA using location (Ames or Nashua), treatment (untreated control, and $3 \mathrm{Cl}$ sources at 3 doses), and cutting ( 1 to 4 of the year 2001), and their interactions as main effects in the model. Location proved to have a great impact on plant mineral composition. Cutting and location $\times$ cutting interactions were also significant effects on plant mineral content.

A factorial ANOVA model that included treatment, cutting, and treatment $\times$ cutting interaction was performed using the GLM procedure of SAS for each location-Ames and Nashua (SAS User's Guide, 1999). This analysis allowed comparison of treatment effects with those of the control plots. When ANOVA suggested a significant effect, post hoc comparisons were made.

The data were also analyzed to examine the effect of the rate of $\mathrm{Cl}$ application $(0,56,112$, or $168 \mathrm{~kg}$ of $\mathrm{Cl} / \mathrm{ha}$ ), regardless of the chemical source of the $\mathrm{Cl}$, across the 4 cuttings harvested in 2001 from each location. Data were analyzed using the REPEATED method of the MIXED procedure of SAS (SAS User's Guide, 1999). This model included rate of $\mathrm{Cl}$ application, cutting, and rate $\times$ cutting interactions. The variation between plots was specified with a RANDOM statement consisting of plot nested within rate of $\mathrm{Cl}$ application. Autoregressive covariance was determined to be the most applicable covariate structure used for all repeated measures analyses (Littell et al., 1998). Each cutting sampled represented a repeated measure of each plot. 
Table 1. Location effects on mean \pm SEM mineral content $(\mathrm{mg} / \mathrm{kg})$ and $\mathrm{pH}$ of soil across all 40 plots at each location in April 2001, prior to application of any of the treatments

\begin{tabular}{|c|c|c|c|c|c|c|c|}
\hline \multirow[b]{2}{*}{ Location } & \multicolumn{6}{|c|}{ Mineral } & \multirow[b]{2}{*}{$\mathrm{pH}$} \\
\hline & Chloride $^{1}$ & Sulfur ${ }^{1}$ & Calcium $^{2}$ & Phosphorus & Magnesium $^{2}$ & Potassium $^{2}$ & \\
\hline Ames & $3.06 \pm 0.18$ & $1.77 \pm 0.05$ & $2,300 \pm 10$ & $26.9 \pm 1.1$ & $463 \pm 3$ & $111 \pm 2.1$ & $6.12 \pm 0.04$ \\
\hline Nashua & $2.26 \pm 0.23$ & $24.4 \pm 2.2$ & $1,583 \pm 10$ & $13.3 \pm 0.9$ & $363 \pm 3$ & $149 \pm 11$ & $5.92 \pm 0.02$ \\
\hline
\end{tabular}

Finally, to discern differences among the 3 sources of $\mathrm{Cl}$ on alfalfa mineral composition and yield, the data from each location were analyzed by repeated measures ANOVA (SAS Institute, 1999). The data obtained from control plots were eliminated from these analyses because there was not a set of control plots designated for each of the $3 \mathrm{Cl}$ sources. This model included source of $\mathrm{Cl}$, rate of application, cutting, source $\times$ rate, rate $\times$ cutting, source $\times$ cutting, and source $\times$ rate $\times$ cutting interactions as main effects. The variation between plots was specified with a RANDOM statement consisting of plot nested within source of $\mathrm{Cl}$ and rate of $\mathrm{Cl}$. Autoregressive covariance was the covariate structure used for all repeated measures analyses (Littell et al., 1998). Each cutting sampled represented a repeated measure of each plot. This analysis was done twiceonce with just the 4 cuttings of 2001 and a second time, which included data from the fifth alfalfa cutting of spring 2002 to determine if treatment effects were carried over the winter.

Mean separations, using the method of TukeyKramer, were computed when significant effects were observed $(P<0.05)$ in the $F$-test.

\section{RESULTS AND DISCUSSION}

\section{Effect of Chloride Application On Soil Mineral Concentrations}

Water-extractable chloride content of the soil prior to application of chloride was $3.06 \pm 0.18 \mathrm{mg} / \mathrm{kg}$ in Ames and $2.26 \pm 0.23 \mathrm{mg} / \mathrm{kg}$ in Nashua. Water-extractable sulfur content of the soil in the Ames and Nashua plots was $1.77 \pm 0.05 \mathrm{mg} / \mathrm{kg}$ and $24.4 \pm 2.2 \mathrm{mg} / \mathrm{kg}$, respectively (Table 1). After application of the chloride, the chloride content of the soil increased with increasing dose of chloride fertilizer when sampled in July 2001. In Ames, fertilizing with 56,112 , or $168 \mathrm{~kg}$ of $\mathrm{Cl} / \mathrm{ha}$ increased soil chloride content to $9.5,14.1$, and $23 \mathrm{mg} / \mathrm{kg}$. The same treatments applied to Nashua plots resulted in soil with water-extractable chloride content of 5.2, 8.5, and $15.6 \mathrm{mg} / \mathrm{kg}$ of soil. This suggests differences exist in the soil chloride binding capacity of the 2 soils. There were no significant differences in plot soil chloride con- tent as affected by source of chloride. Application of chloride did not significantly change the soil content of any other minerals.

\section{Alfalfa Mineral Content}

Location was a significant factor affecting all alfalfa mineral concentrations, with the exception of $\mathrm{P}$ content. Alfalfa harvested from the Ames location control plots had higher $\mathrm{Cl}, \mathrm{Ca}, \mathrm{Mg}$, and $\mathrm{Na}$ than alfalfa harvested from the Nashua location control plots. Alfalfa K and $\mathrm{S}$ concentrations were higher in the Nashua plots. The DCAD was also higher in the alfalfa from the plots in Nashua. Alfalfa yield from control plots across the first 4 cuttings was similar in the Ames and Nashua locations. The cutting of alfalfa within the 2001 growing season also had a large effect on $\mathrm{Cl}$ content, DCAD, and yield in both locations (data not shown).

Across both locations, and within each location, the application of $\mathrm{Cl}$ increased alfalfa $\mathrm{Cl}$ content when compared with control plots (Tables 2 and 3). Application of chloride from $\mathrm{NH}_{4} \mathrm{Cl}, \mathrm{CaCl}_{2}$, or the mixture of $\mathrm{NH}_{4} \mathrm{Cl}$ and $\mathrm{CaCl}_{2}$, increased alfalfa $\mathrm{Cl}$ content equally well. Repeated measures ANOVA using rate of $\mathrm{Cl}$ application, cutting, and rate by cutting as main effects demonstrated application of $112 \mathrm{~kg}$ of $\mathrm{Cl} / \mathrm{ha}$ from any source was able to increase alfalfa $\mathrm{Cl}$ more than application of $56 \mathrm{~kg}$ of $\mathrm{Cl} / \mathrm{ha}$. However, no further increase in alfalfa $\mathrm{Cl}$ was observed in alfalfa from plots treated with 168 $\mathrm{kg}$ of $\mathrm{Cl} / \mathrm{ha}$. Although $\mathrm{Cl}$ was applied to the plots just once in the spring, there was no indication that there was a graded diminution of alfalfa $\mathrm{Cl}$ content with each succeeding harvest in the 2001 growing season. However, the first cutting of alfalfa made in the spring of 2002 was significantly lower in $\mathrm{Cl}$ than any of the cuttings made in 2001, suggesting depletion of $\mathrm{Cl}$ from the soil over the winter. Chloride treatments had no effects on alfalfa $\mathrm{Na}, \mathrm{S}, \mathrm{K}, \mathrm{Mg}, \mathrm{Ca}$, or $\mathrm{P}$ content.

Across the 4 cuttings of 2001 and across both locations $\mathrm{CaCl}_{2}$ applied at $168 \mathrm{~kg}$ of $\mathrm{Cl} / \mathrm{ha}$ depressed alfalfa yield from that in control plots (Table 2). Lower doses of $\mathrm{CaCl}_{2}$, and all other $\mathrm{Cl}$ treatments, did not affect yield significantly. However, the $168 \mathrm{~kg}$ of Cl/ha dose, regardless of source, tended to depress yield, especially at first 
Table 2. Effect of chloride source and treatment level on plant yield, mineral content (\% DM), and DCAD 1

\begin{tabular}{|c|c|c|c|c|c|c|c|c|c|c|c|}
\hline \multirow[b]{3}{*}{ Variable } & \multirow{3}{*}{$\frac{\text { Control }}{0}$} & \multicolumn{9}{|c|}{ Chloride source $(\mathrm{kg}$ of $\mathrm{Cl} / \mathrm{ha})$} & \multirow[b]{3}{*}{ MSE } \\
\hline & & \multicolumn{3}{|c|}{$\mathrm{NH}_{4} \mathrm{Cl}$} & \multicolumn{3}{|c|}{$\mathrm{CaCl}_{2}$} & \multicolumn{3}{|c|}{ Mix } & \\
\hline & & 56 & 112 & 168 & 56 & 112 & 168 & 56 & 112 & 168 & \\
\hline Chloride $^{2}$ & $0.52^{\mathrm{a}}$ & $0.77^{\mathrm{b}}$ & $0.87^{\mathrm{c}}$ & $0.86^{\mathrm{c}}$ & $0.77^{\mathrm{b}}$ & $0.87^{\mathrm{c}}$ & $0.89^{c}$ & $0.78^{b}$ & $0.88^{\mathrm{c}}$ & $0.91^{\mathrm{c}}$ & 0.10 \\
\hline Sodium $^{2}$ & $0.10^{\mathrm{a}}$ & $0.11^{\mathrm{a}}$ & $0.11^{\mathrm{a}}$ & $0.11^{\mathrm{a}}$ & $0.10^{\mathrm{a}}$ & $0.10^{\mathrm{a}}$ & $0.11^{\mathrm{a}}$ & $0.11^{\mathrm{a}}$ & $0.11^{\mathrm{a}}$ & $0.11^{\mathrm{a}}$ & 0.03 \\
\hline Potassium $^{2}$ & $2.17^{\mathrm{a}}$ & $2.10^{\mathrm{a}}$ & $2.24^{\mathrm{a}}$ & $2.23^{\mathrm{a}}$ & $2.17^{\mathrm{a}}$ & $2.27^{\mathrm{a}}$ & $2.19^{\mathrm{a}}$ & $2.17^{\mathrm{a}}$ & $2.23^{\mathrm{a}}$ & $2.27^{\mathrm{a}}$ & 0.27 \\
\hline Sulfur $^{2}$ & $0.26^{\mathrm{a}}$ & $0.26^{\mathrm{a}}$ & $0.26^{\mathrm{a}}$ & $0.24^{\mathrm{a}}$ & $0.25^{\mathrm{a}}$ & $0.26^{\mathrm{a}}$ & $0.26^{\mathrm{a}}$ & $0.26^{\mathrm{a}}$ & $0.25^{\mathrm{a}}$ & $0.26^{\mathrm{a}}$ & 0.03 \\
\hline $\mathrm{DCAD}^{3}$ & $288^{\mathrm{a}}$ & $210^{\mathrm{b}}$ & $213^{\mathrm{b}}$ & $223^{\mathrm{b}}$ & $229^{b}$ & $211^{\mathrm{b}}$ & $194^{\mathrm{b}}$ & $221^{b}$ & $209^{b}$ & $209^{b}$ & 67 \\
\hline Yield $^{4}$ & $3.07^{\mathrm{a}}$ & $2.87^{\mathrm{ab}}$ & $2.82^{\mathrm{ab}}$ & $2.84^{\mathrm{ab}}$ & $3.07^{\mathrm{a}}$ & $2.91^{\mathrm{ab}}$ & $2.64^{\mathrm{bc}}$ & $3.02^{\mathrm{a}}$ & $2.93^{\mathrm{ab}}$ & $2.76^{\mathrm{ab}}$ & 0.45 \\
\hline
\end{tabular}

${ }^{\mathrm{a}-\mathrm{c}}$ Means within a row with differing superscripts are significantly different, $P<0.05$.

${ }^{1}$ Values represent LS means and MSE derived from factorial ANOVA across all 4 cuttings at the Nashua and Ames locations from the 2001 growing season.

$2 \%$ of DM.

${ }^{3} \mathrm{mEq}$ of $\left(\mathrm{Na}^{+1}+\mathrm{K}^{+1}\right)-\left(\mathrm{Cl}^{-1}+\mathrm{SO}_{4}^{-2}\right) / \mathrm{kg}$ of $\mathrm{DM}$.

${ }^{4}$ t/ha.

cutting of alfalfa in both locations. Cutting had a major effect on yield, but a cutting $\times$ treatment effect on yield was not observed.

Across both locations, chloride application decreased alfalfa DCAD when compared with the control plots (Table 2). This effect was greatest in the plots in Nashua (Table 3), probably because DCAD in Ames was already considerably lower in control plots, as a result of lower $\mathrm{K}$ and higher $\mathrm{Cl}$ concentration than in control plots in Nashua.

Feeding high DCAD forages to dairy cows in late gestation is a well-documented means of inducing hypocalcemia and milk fever in dairy cows (Ender et al., 1971; Goff and Horst, 1997). Potassium concentration in alfalfa tissues can often range from a low of 1.2 to $1.6 \%$ up to 3.6 to $4.2 \%$ (Lanyon and Smith, 1985). Because $\mathrm{K}$ is the major cation contributing to high DCAD diets, an obvious solution is to limit $\mathrm{K}$ application to avoid luxury consumption of $\mathrm{K}$ by the forage crop. How- ever, alfalfa containing less than 2.1 to $2.3 \% \mathrm{~K}$ may have reduced yield and winter survival (Lanyon and Smith, 1985; Kelling and Matocha, 1990). Thus, producing alfalfa with less than $2.1 \% \mathrm{~K}$ is not profitable, especially in northern regions.

The high DCAD of alfalfa and many grasses has caused a shift toward increased reliance on corn silage as the forage source for dry cows. Unfortunately the physically effective fiber of corn silage can vary, and lack of effective fiber can lead to increased incidence of displaced abomasum. Feeding low DCAD dry hay in the close-up ration could benefit rumen and abomasal functions. Using the results of alfalfa plots in Nashua as an example, the potassium content of the alfalfa was $24 \mathrm{~g} / \mathrm{kg}$, a level that would be expected to support maximal yield. The DCAD in the control plots was +390 $\mathrm{mEq} / \mathrm{kg}$ of DM. Feeding $4 \mathrm{~kg} / \mathrm{d}$ of control alfalfa hay to enhance effective fiber would alter the DCAD of the ration by a net $+1,560 \mathrm{mEq}$. If instead we use the high

Table 3. Effect of location and rate of chloride application on plant chloride content (\% DM), DCAD, and yield across all cuttings of 2001 at the Ames and Nashua locations ${ }^{1}$

\begin{tabular}{llcccc}
\hline & & \multicolumn{4}{c}{ Rate $(\mathrm{kg}$ of Cl/ha) } \\
\cline { 3 - 6 } Location & Variable & \multicolumn{1}{c}{0} & 50 & 100 & 150 \\
\hline \multirow{2}{*}{ Ames } & Chloride $^{2}$ & $0.77 \pm 0.04^{\mathrm{a}}$ & $0.92 \pm 0.02^{\mathrm{b}}$ & $1.01 \pm 0.02^{\mathrm{c}}$ & $0.99 \pm 0.02^{\mathrm{c}}$ \\
& DCAD $^{3}$ & $184 \pm 23.0^{\mathrm{a}}$ & $138 \pm 13.0^{\mathrm{a}}$ & $154 \pm 13.5^{\mathrm{a}}$ & $152 \pm 13.5^{\mathrm{a}}$ \\
& Yield $^{4}$ & $3.15 \pm 0.13^{\mathrm{a}}$ & $3.02 \pm 0.09^{\mathrm{a}}$ & $2.89 \pm 0.07^{\mathrm{a}}$ & $2.82 \pm 0.07^{\mathrm{a}}$ \\
& Chloride $^{2}$ & $0.29 \pm 0.03^{\mathrm{a}}$ & $0.63 \pm 0.02^{\mathrm{b}}$ & $0.74 \pm 0.02^{\mathrm{c}}$ & $0.79 \pm 0.02^{\mathrm{c}}$ \\
& DCAD $^{3}$ & $390 \pm 18^{\mathrm{a}}$ & $300 \pm 11^{\mathrm{b}}$ & $267 \pm 11^{\mathrm{c}}$ & $266 \pm 11^{\mathrm{c}}$ \\
& Yield $^{4}$ & $2.97 \pm 0.11^{\mathrm{a}}$ & $2.95 \pm 0.07^{\mathrm{a}}$ & $2.91 \pm 0.07^{\mathrm{a}}$ & $2.66 \pm 0.07^{\mathrm{b}}$ \\
\hline
\end{tabular}

${ }^{\mathrm{a}-c}$ Means within a row with differing superscripts are significantly different, $P<0.05$.

${ }^{1}$ Values represent LS means and MSE derived from factorial ANOVA across all chloride sources and across all 4 cuttings from the 2001 growing season.

$2 \%$ of DM.

${ }^{3} \mathrm{mEq}$ of $\left(\mathrm{Na}^{+1}+\mathrm{K}^{+1}\right)-\left(\mathrm{Cl}^{-1}+\mathrm{SO}_{4}{ }^{-2}\right) / \mathrm{kg}$ of DM.

${ }^{4} \mathrm{t} / \mathrm{ha}$. 
$\mathrm{Cl}$ alfalfa from plots receiving $112 \mathrm{~kg}$ of $\mathrm{Cl} / \mathrm{ha}$, we would be adding just $+1,068 \mathrm{mEq}$ cation to the ration. About half an equivalent less anion would need to be added from anionic salts to achieve the same final DCAD in the total ration. We believe anions coming into the diet through the forage would be more palatable than anions supplied from sources such as ammonium chloride or calcium chloride. However, studies have not been conducted at this time to verify this.

Thomas (1996) and Thomas et al. (1998) have previously demonstrated that applying chloride to grass species could reduce DCAD of grass hays. They fertilized reed canarygrass with $56 \mathrm{~kg}$ of Cl/ha, and the grass $\mathrm{Cl}$ content rose from $7.2 \mathrm{~g} / \mathrm{kg}$ in control plots to $14.2 \mathrm{~g} /$ $\mathrm{kg}$ in $\mathrm{Cl}$ fertilized plots. Pehrson et al. (1999) explored the effects of $\mathrm{K}_{2} \mathrm{SO}_{4}$ and $\mathrm{KCl}$ added to soil on grass DCAD. Addition of $\mathrm{SO}_{4}$ to the soil did not alter plant sulfur or DCAD content. Application of $\mathrm{Cl}$ increased plant chloride content and reduced DCAD.

Pelletier et al. (2007) recently examined the influence of increasing rates of chloride and nitrogen application on DCAD of timothy grass. In these studies addition of chloride increased plant chloride content and reduced DCAD in a quadratic fashion that plateaued at a certain rate of chloride application dependent on soil and season of plant growth. They used both ammonium chloride and calcium chloride to supply the chloride. The 2 sources of chloride were equally effective in reducing DCAD of the timothy hays. They also found a small but significant reduction in DCAD of timothy hays could be achieved by nitrogen application alone if soil $\mathrm{K}$ was low or moderate, but not if soil $\mathrm{K}$ was high. This treatment also increased plant yield. This study found that the economically optimal application rate of chloride fertilizer was between 78 and $123 \mathrm{~kg}$ of $\mathrm{Cl} / \mathrm{ha}$, depending on soil $\mathrm{K}$ and $\mathrm{Cl}$ content prior to application.

The results of the present study extend these findings by demonstrating that adding $\mathrm{Cl}$ to the soil can alter alfalfa tissue $\mathrm{Cl}$ concentration. At Nashua, the addition of $56 \mathrm{~kg}$ of $\mathrm{Cl} / \mathrm{ha}$ more than doubled alfalfa $\mathrm{Cl}$ content, but the increase was not as dramatic at Ames (Table 3 ). The pretreatment soil water-extractable $\mathrm{Cl}$ was higher at Ames than Nashua (3.06 vs. $2.26 \mathrm{mg} / \mathrm{kg}$ ), and a large difference in alfalfa $\mathrm{Cl}$ content from the control plots in the 2 sites was evident as well $(2.9 \mathrm{~g} / \mathrm{kg}$ in Nashua vs. $7.7 \mathrm{~g} / \mathrm{kg}$ in Ames). In both locations, increasing the dose of $\mathrm{Cl}$ from 56 to $112 \mathrm{~kg}$ of $\mathrm{Cl} /$ ha further increased alfalfa $\mathrm{Cl}$ content, but increasing $\mathrm{Cl}$ application from 112 to $168 \mathrm{~kg}$ of Cl/ha did not significantly increase $\mathrm{Cl}$ content of alfalfa any further. This observation is difficult to understand. In Ames, the assumption might be made that application with $112 \mathrm{~kg}$ of $\mathrm{Cl} / \mathrm{ha}$ met or exceeded the soil $\mathrm{Cl}$ level required to maximize alfalfa $\mathrm{Cl}$ content (about $1 \% \mathrm{Cl}$ in Ames). In Nashua, despite the lower soil $\mathrm{Cl}$ and lower $\mathrm{Cl}$ content of alfalfa from control plots, $112 \mathrm{~kg}$ of Cl/ha also maximized alfalfa $\mathrm{Cl}$ uptake. About $0.8 \% \mathrm{Cl}$ was the maximal $\mathrm{Cl}$ content achieved in Nashua. The same alfalfa cultivar was planted in each location, and yet maximal achievable $\mathrm{Cl}$ content differed in the 2 locations. Differences in rainfall or soil anion-binding capacity could be responsible for these differences.

Interestingly, soil water-extractable $\mathrm{S}$ content in Nashua was 13-fold greater than in Ames. Though alfalfa S was significantly higher in alfalfa from Nashua the differences were small, averaging $0.28 \% \mathrm{~S}$ in Nashua and 0.24\% in Ames. Pehrson et al. (1999) and E. D. Thomas (personal communication, Miner Institute, Chazy, NY) have observed that utilizing S application as a means of adjusting forage DCAD does not hold great promise.

The DCAD was not as greatly affected by application with $\mathrm{Cl}$ as was the alfalfa $\mathrm{Cl}$ content. The formula for DCAD is calculated as the $\mathrm{mEq} / \mathrm{kg}(\mathrm{Na}+\mathrm{K})-(\mathrm{Cl}+\mathrm{S})$. The concentration of $\mathrm{K}, \mathrm{Na}$, and $\mathrm{S}$ in the plants varied among cuttings, and these differences introduced sufficient variability into the DCAD equation to overshadow the effects that increased $\mathrm{Cl}$ content had on DCAD calculations.

Although Cl-treated plots tended to yield less than the control plots, the differences are, with a few exceptions at the highest $\mathrm{Cl}$ application rate, not statistically significant. Analysis of data combined across locations indicated that the $\mathrm{Cl}$ application had the largest effect on yield at the first cutting of alfalfa and at the highest doses of $\mathrm{Cl}$. The alfalfa plants had begun their spring growth at the time the $\mathrm{Cl}$ treatments were applied, and within a few days of application, we observed browning of some of the emerged tissue. Earlier application of the $\mathrm{Cl}$ to the soil, before the crowns had emerged, may avoid burning the plants, and may not affect yield as greatly. Autumn application of $\mathrm{Cl}$ following the final harvest of the year might also be considered. Our data suggest that $\mathrm{Cl}$ application once in the spring increased $\mathrm{Cl}$ content of alfalfa harvested during that growing season, but did not carry over very well into the next spring's harvest. Whether the harvested alfalfa depleted the soil of the $\mathrm{Cl}$ or winter snowmelt leached the $\mathrm{Cl}$ is unknown.

Future experiments will need to determine whether bringing anions into the ration within forages proves more palatable to the cow than current efforts to reduce diet DCAD by addition of anion supplements directly to the ration. If chloride entering the ration within forages does not result in a significantly more palatable ration than when chloride sources are added directly to the ration, it is unlikely to be an economical means of preventing hypocalcemia in cows fed TMR. Chloride ap- 
plied to forage in fields may still prove useful in management of late gestation dairy cows fed pasture.

\section{CONCLUSIONS}

This experiment was designed to assess an alternative method of manipulating DCAD (i.e., raising the $\mathrm{Cl}$ content of alfalfa to produce lower DCAD forages for the dry dairy cow) as an aid in the effort to reduce periparturient hypocalcemia. Increasing the $\mathrm{Cl}$ content of alfalfa forage makes it more useful as a feed ingredient in the ration of cows in late gestation. The addition of $112 \mathrm{~kg}$ of Cl/ha ( $100 \mathrm{lb}$ of Cl/acre), regardless of source used in this study, maximized alfalfa $\mathrm{Cl}$ content and had minimal negative effects on yield. This effect was observed across all 4 cuttings of alfalfa in the year the alfalfa plots were fertilized. However, the effect did not carry over after the winter because spring cuttings of the following year had similar chloride content to the control plots. The sources of $\mathrm{Cl}\left(\mathrm{CaCl}_{2}, \mathrm{NH}_{4} \mathrm{Cl}\right.$, or the mixture of the 2) had no differential effect on alfalfa $\mathrm{Cl}$ content, DCAD, or yield. The choice of $\mathrm{Cl}$ source would be dictated by cost, ease of application to the fields, or both. Chloride application of forages may offer another means of reducing DCAD of the prepartum dairy cow diet. Further tests will be required to assess palatability of chloride coming into the prepartal diet from forages vs. from added inorganic mineral sources.

\section{REFERENCES}

Block, E. 1984. Manipulating dietary anions and cations for prepartum dairy cows to reduce incidence of milk fever. J. Dairy Sci. 67:2939-2948.

Dishington, I. W. 1975. Prevention of milk fever (hypocalcemic paresis puerperalis) by dietary salt supplements. Acta Vet. Scand. 16:503-512.

Ender, F., I. W. Dishington, and A. Helgebostad. 1971. Calcium balance studies in dairy cows under experimental induction and prevention of hypocalcaemic paresis puerperalis. The solution of the aetiology and the prevention of milk fever by dietary means. Z. Tierphysiol. Tierernahr. Futtermittelkd. 28:233-256.

Goff, J. P., and R. L. Horst. 1997. Effects of the addition of potassium or sodium, but not calcium, to prepartum rations on milk fever in dairy cows. J. Dairy Sci. 80:176-186.

Goff, J. P., and R. L. Horst. 1998. Use of hydrochloric acid as a source of anions for prevention of milk fever. J. Dairy Sci. 81:2874-2880.

Goff, J. P., R. L. Horst, F. J. Mueller, J. K. Miller, G. A. Kiess, and H. H. Dowlen. 1991. Addition of chloride to a prepartal diet high in cations increases 1,5-dihydroxyvitamin D response to hypocalcemia preventing milk fever. J. Dairy Sci. 74:3863-3871.

Kelling, K. A., and J. E. Matocha. 1990. Plant analysis as an aid in fertilizing forage crops. Pages 603-642 in Soil Testing and Plant Analysis. Vol. Chapter 23. 3rd ed. R. L. Westerman, ed. Soil Sci. Soc. Am., Madison, WI.

Lanyon, L. E., and F. W. Smith. 1985. Potassium nutrition of alfalfa and other forage legumes: Temperate and tropical. Pages 861893 in Potassium in Agriculture, Vol. Chapter 37. R. D. Munson, ed. Am. Soc. Agron.-Crop Sci. Soc. Am.-Soil Sci. Soc. Am., Madison, WI.

Littell, R. C., P. R. Henry, and C. B. Ammerman. 1998. Statistical analysis of repeated measures data using SAS procedures. J. Anim. Sci. 76:1216-1231.

Mertens, D. R. 1997. Creating a system for meeting the fiber requirements of dairy cows. J. Dairy Sci. 80:1463-1481.

National Animal Health Monitoring Survey (NAHMS). 2002. Dairy 2002, Part I: Reference of Dairy Health and Management in the United States. USDA-Animal and Plant Health Inspection Service, Fort Collins, CO.

Pehrson, B., C. Svensson, I. Gruvaeus, and M. Virkki. 1999. The Influence of acidic diets on the acid-base balance of dry cows and the effect of fertilization on the mineral content of grass. J. Dairy Sci. 82:1310-1316.

Pelletier, S., G. Bélanger, G. F. Tremblay, P. Seguin, R. Drapeau, and G. Allard. 2007. Dietary cation-anion difference of Timothy (Phleum pratense L.) as influenced by application of chloride and nitrogen fertilizer. Grass Forage Sci. 62:66-77.

SAS User's Guide. 1999. Statistics, V. SAS Institute Inc., Cary, NC.

Thomas, E. D. 1996. What we're learning about growing grasses for dry cows. Hoard's Dairyman 141:224.

Thomas, E. D., C. J. Sniffen, C. J. Majewski, and C. S. Ballard. 1998. Reed Canarygrass response to nitrogen and chloride fertilization. Miner Agric. Res. Inst., Chazy, NY.

Warncke, D., and J. R. Brown. 1998. Potassium and other basic cations. Pages 31-33 in Recommended Chemical Soil Test Procedures for the North Central Region. North Central Regional Res. Publ. 221 (rev.). J. R. Brown, ed. Missouri Agric. Exp. Stn. SB 1001, Columbia. 